\title{
A Novel is a Lengthy Question: An Interview with Frank Ronan
}

\author{
By Valentina Milli \\ University of Florence
}

Copyright (c) 2007 by Valentina Milli. This text may be archived and redistributed both in electronic form and in hard copy, provided that the author and journal are properly cited and no fee is charged for access.

Frank Ronan has published a collection of short stories, Handsome Men Are Slightly Sunburnt (1996), and six novels, The Men Who Loved Evelyn Cotton (1989), A Picnic in Eden (1991), The Better Angel (1992), Dixie Chicken (1994), Lovely (1996) and Home (2002), many of which have been translated into French, Spanish, German, Portuguese, Italian, Greek and Dutch. It is extremely difficult to pigeonhole Ronan's writing and, according to him, it is also pointless since "it's always the people who don't read books who want to categorise them". The following interview throws some new light on this brilliant contemporary Irish writer and his multifarious areas of interest.

Key Words. Frank Ronan, the masculine body, childhood, love, the Sixties, religion, nature.

Frank Ronan ha publicado una colección de relatos titulada Handsome Men Are Slightly Sunburnt (1996), y seis novelas, The Men Who Loved Evelyn Cotton (1989), A Picnic in Eden (1991), The Better Angel (1992), Dixie Chicken (1994), Lovely (1996) y Home (2002), muchas de las cuales han sido traducidas al francés, castellano, alemán, portugués, italiano, griego y holandés. Es sumamente difícil clasificar la obra de Ronan y, según él, es también un empeño vano, puesto que "es siempre la gente que no lee libros quienes quieren etiquetarlos". La siguiente entrevista aporta una nueva perspectiva sobre este brillante escritor contemporáneo irlandés y sobre sus diversas áreas de interés.

Palabras clave. Frank Ronan, cuerpo masculino, infancia, amor, los años sesenta, religión, naturaleza.

\section{When did you understand that you were going to be a novelist?}

Well, I think you already are a novelist and you can't become one. So it is just a question of coming to terms with it. When I was about fifteen I used to be a poet and I started to read my poetry and I met a lot of famous poets and they didn't seem very happy. As I wanted to be happy, I decided that I didn't want to be a poet and that I should try with novels. Then I started
The Better Angel, which is the first novel I wrote. I started writing it when I was seventeen. So, the correct answer to your question is: at the age of seventeen years and one month I realised I was a novelist. I mean, I think that being a novelist is a bit like being gay, it's not something you can suddenly decide one day, but you just have to come to terms with that and try to work out how to fit it in your life or make it your life.

ISSN 1699-311X 
During an interview for the Irish Times (Boland 1996), you defined yourself as a 'substantialist', someone who is primarily interested in the ideas and the content of fiction, rather than being a 'stylist', someone who is mostly concerned with experimental forms of narration. Does this mean that you started writing because you felt urged to express a precise message to your readers?

No. I think to be primarily a 'stylist' is a waste of time and a waste of life. And if you want to be a stylist you can do something else, you can go and write for a magazine or you can be Tom Wolfe. I am not interested in reading the stylists. To be really worthwhile, a novel has to have an idea at its core and you have to have something to say, whether you succeed in saying it or not. When you are reading a novel, you can sense always whether it is driven by an idea or whether it is driven by the novelist's desire to have people think him clever. That's what I find about the stylists: they're not interested in making something wonderful, they just want people to say how clever they are. That's why I am a 'substantialist'. Then, whether I have anything to communicate to my readers...I think it cannot be so specific and that, in a funny way, I have quite Jungians ideas about it. I hate to get Platonic, but there is a sense in which the novelist doesn't have to know what the idea is, but the idea is in one place and the reader is in another place and the novelist becomes the medium, the portal for the reader to access the idea. Sometimes, the novelist doesn't have to understand the idea. It's better if you do, of course. What I want to say is that I am not a polemical writer, I don't have a belief which I am trying to convince the reader of. I have questions which I want to ask in a lengthy way and the novel is a lengthy question. By reading it, the reader should have a question. It may not be the same question that the novelist had when he was writing it, but as long as there is a question, that's the thing. You know, in a novel which is purely about style, there are no questions, but the reader is only supposed to say "Oh Gosh! I didn't know you could do that with an adjective. How clever!”

Your passion for botany is expressed throughout your work. The garden is very often a place where characters find their inner selves: in A Picnic in Eden, Adam Parnell and his wife Norah own a nursery and like to spend their holidays in the beautiful landscapes of Scotland where he eventually gets the chance to explore his past and to find a real friend; in Home, young Coorg learns how to grow plants in the hippy commune where he lives and, once he is kidnapped and brought to Ireland, his garden becomes the best place to be for him. Nature is crucial to the characters of the other novels, too. In Dixie Chicken, after having grown up in a shack on a mountain, Rory Dixon goes to Dublin and then buys a house in the country where he chooses to commit suicide, throwing himself into the Irish sea, thus choosing nature and solitude as the best death after a very mundane life. The Better Angel, set in Wexford, is deeply tied to the rhythms of the land because the protagonist owns a farm. The countryside becomes a sort of Eden, far from social constrictions, where man can express himself freely. Can nature be read as a metaphor for these men's deep need for a reconciliation with their origins? Or rather as a sort of non-place where they can forget the traumas of their lives?

It's both. Basically, most people don't even see plants, and plants are so important. Plants make the air we breathe, and everything we eat comes from plants, directly or indirectly. Then, gardening is the best thing you can do on your own, actually. If you want to spend time on your own doing something, it's the most satisfying and interesting activity. And what's amazing about garden plants, which are basically all clones, is that if you kill one, you can get another one which is exactly the same. They can't break your heart like animals. It's a very safe place to put your love. Yes, it is a refuge for characters. It has to do with my perception. But, maybe, one day I'll write about a character who has to be a gardener and hates it, that would be interesting... that would be the best thing to do. I think that botany is a great undervalued science. It should be one of our primary duties as humans to always notice the plants, what they're doing, and why they're doing it, everywhere we go, because our lives depend on them. I don't want to get new age about that, but an awful lot of people are really 
blind, have never sat down and thought where they are. This is one of the terrible things that religion has done, it's telling that everyone is here because God wants them to be here. Gardening has to do with a much deeper miracle of chemistry, of physics and of botany and it's so much more interesting than a made up fairy story. I think gardens are essential, and I think if the human race becomes more civilised, then, they will become more essential to everyone. Particularly, as the wild has been destroyed by globalisation and technology, it becomes so important to make these spaces where nature is still allowed. Of course, gardens, even the wildest ones, are artificial constructions, but, certainly, in Europe, there is no natural landscape. The landscape, even in the most remote places, has been managed now for ten thousand years and gardens are the closest you can get to be natural. I cannot suppress these feelings in my writing.

\section{Would you define your work as autobiogra- phical?}

No. But that doesn't mean that it couldn't be defined autobiographically. I think it's important that I don't, because the purpose is not autobiographical. If my purpose was autobiographical, I'd rather write an autobiography. The thing is when you have a novel to write, you would use everything you can and to use autobiographical details is easy. You know, you need to give your chief character a profession; you can't make him a novelist, that's stupid. I had a friend who was a thatcher, so Hugh in Evelyn Cotton became a thatcher. So I could phone my friend and ask what's the name of those things he wears on his knees and, because I had been talking to him and he had described his work to me and I had been on the roof with him and seen what it was like, that's why that character is a thatcher. In A Picnic in Eden, the protagonist is a nurseryman because I had friends who were nurserymen. So, it doesn't mean that I am writing about thatchers and nurserymen in a biographical way any more than details that coincide with my life are autobiographical. It's just the way I am getting the facts right. So, in Home, Coorg has exactly the same birth date as me and, from the age of six, lives in the same places I lived in. But he's not me, it's not the story of my life. While I'm writing it, I can instantly know what age he was at that time, what the events were and how he felt about those events as a person of that age. It just makes it easier.

Religion is a common subject of your novels. Many of the characters in your books attend Catholic schools and you too were educated at a Christian Brothers school. You usually offer a negative description of clergy, not only in the fields of Education and Health, but also within the Church itself - for example, the sermon of Duncannon's priest in Home is a tragic portrait of the Church's censorship of human thought. The ironic God of Dixie Chicken, disgusted by Catholic bigotry and so deeply disappointed with his own creation that he stops speaking to them, echoes the image of a terrible father who has decided to ignore his children and throws a pessimistic light on human efforts of getting in touch with the divine sphere. Atheism paradoxically becomes the best way to be in God's graces. What is your attitude towards religion and God?

I think that there is a strong possibility that God exists, but there is an absolute certainty that he is not anything like any human has ever imagined him to be. So, religion is something that comes along and says "God is this way". I mean, how stupid is that! It's funny, it's comedy, but except for the misery it causes in the lives of the adherents of religion. The best thing of the human condition is perception. What we have that other animals don't have is a sentium, a sense of history, of future, of perception, of an ability to think about the end of life which we don't think animals have. People think that elephants might have it, but I don't know. So we have this kind of great potential for fear, and religion could be a comfort for this fear, could be a philosophy, a way of developing thought, but, in fact, it's the opposite, it's something that is used by political institutions to manipulate this fear and to control populations. I think religion, as opposed to any kind of sense of spirituality, is quite different. Religion is an inherently evil development in humanity. It's not just Catholicism. When you go to South America and you look at what the Incas were doing among the population, it's not nice. I mean, in India, it's better. India has always been much more civilised about religion and had a much broader grasp of man's place in the universe, a 
kind of speck of dust. And in Hinduism there is no certainty, good can be bad and bad can be good and it's wonderful from that point of view. But, really, even there, now you see that Hindu fundamentalism has been used to manipulate the population, and to create hatred and xenophobia. I grew up in a society where, at the time, the greatest ills could be laid at the door of the dominant Catholic religion and it's not a surprise that religion comes so strongly in my writing. When the English ruled Ireland and the Catholic Church was the oppressed thing, it was easy to say that it was the English that were evil. But that was nothing compared to what the Church did in Ireland, nothing. You know, the English didn't lock up pregnant girls and obliged them to be silent.

What do you like to read? Was your education influenced by an author or a book in particular?

What I read... I don't like this question because I don't think it's healthy for me to analyse it. I don't have an academic background, save your presence. Academics analyse things to death and nine times out of ten they're wrong, but it doesn't even matter to them because that's how they make their living, whether it is true or not. I don't think one should analyse oneself in that way. Occasionally someone points something out and you think, "Oh, yes, probably...". The influences don't always come from the books or the places you like. If one was writing charming fairy stories to be nice, then, yes, you could say this is my favourite book that inspires me. But, quite often, a book that you really love you have to be careful with, you have to shut it out because the influence could be too strong. It's not very helpful to you, I know, but the best way for me is not to analyse it and, of course, I can come out with some key-texts, those where, at certain points, you suddenly saw the light and thought, "Oh, so that's what it is about". [...] Writing and reading are not two sides of the same thing. I mean, you can't be a writer without being a reader, but you can be a reader without being a writer. So it doesn't feed backwards and forwards in that way. I'm sure there are influences, I'm sure that Enid Blyton is as big an influence as is Samuel Beckett, but I'm not going to ever try to analyse the percentages. I think that's pointless. The important thing is not where the texts came from, but the text that is in front of you. I'm really beginning to think that all novels should be anonymous with no biographical details on the back. But, at the same time, when I read somebody else's novels, I immediately go to the back to read.... Again, it's like smoking, you want to do it, but it's bad.

\section{Many of your novels are set in the sixties or are concerned with men who grew up during those years and were thus deeply influenced by their ideologies. Instead of emphasising the myth of the revolutions of the sixties, you are mostly interested in giving an ironic and disillusioned description of the failures and contradictions of the counterculture. Even if, as in the case of Dixie Chicken and Home, the experiences of the English hippies are shown in opposition to the more provincial nature of Irish life, neither of them is to be considered healthy.}

I think the sixties were an absolute hinge point in human civilisation. I don't think there is any question about that in my mind. The fact that I was a small child when this was happening, in a country where it didn't happen, is maybe part of the fascination. Because all was going on somewhere else, while I was alive. Little bits and little glimpses came through. I would be with my mother in the town and there would be a woman in a mini-skirt. I would say to my mother, "Why is her skirt so short?" and she would say, "She's only showing off. Don't look". My aunt Stephanie went to Spain, she played the guitar and she came back wearing jeans and there was a scandal in the town: she was wearing jeans in 1969! I don't know if I am too hard on the hippies in Home. The hippies were very funny, any idealist is funny. At the moment you become an idealist you become humorous because you lose your sense of proportion. Even with the best of intentions, they did jolly stupid things. I don't mean to be cruel.. I like that kind of juxtaposition because it was quite funny that a lot of hippies, more during the seventies when the counterculture collapsed in England and in America, came to Ireland looking for some kind of idyll, some kind of Gothic charm. From San Francisco, or Notting Hill, or whatever, they had idealised the countryside and then came and found it full of a lot of people who didn't want them or 
understand them. That is inherently comic. But I think mostly it's because it's something that happened while I was on the same planet but I was denied it.

The body plays a crucial role in your novels. The masculine body causing troubles to its bearer can easily be compared to the Feminist concern with the female body being a burden for women. Evelyn Cotton was defined by Gerard Gardiner (1989) as a 'dramatic exploration of Feminism from a male standpoint'. Do you agree with this comment?

I'd rather say it was a 'novelistic exploration of Feminism from a male standpoint'. I don't know what to think about this. Feminism has liberated men as much as it has liberated women, they just don't know it yet. And in a Post-Feminist society, men can write about things they weren't allowed to write about before, including insecurities about their body. Those authors like Hemingway had to pretend that they had the biggest dick and a good go all night. In the thirties, the male body was for killing elephants. Even D. H. Lawrence, who came the closest to being honest about sex and corporeal matters, idealised the male body and made the penis bigger and the stomach muscles flatter. It's only now, after Feminism, that men can feel more relaxed about that. The male body is a burden as much as the human body is a burden. Things that had never been spoken about before, but actually are perfectly ordinary. If you live in a society with taboos, it's very embarrassing for teenage boys to deal with their bodies. While, if you live in a society where sex is referred to, it's just a little bit embarrassing, but only in a way that you can be teased about. That's very recent. In a Pre-Feminist society, men suffered hideous agonies about masturbation, night emissions and all these stupid things that, really, are nothing to get depressed about. And so we have Feminism to thank for that, I think. What came in with Feminism was a great honesty about sexuality. Of course, first you had more honesty about sexuality, before Feminism, but, then, Feminism started to make that openness... I mean, who knows... we're still in a state of rapid evolution with all these things. Sexuality is still a sort of no man's land. Is the naked body a good thing or a bad thing? Obviously, it depends how you feel about the person whose body is naked. I mean, the question is: should it be private or public? You don't want to see other people's bits swinging around, but, at the same time, if it's all made private and secret, that's not good either. Before, modesty and secrecy was normality and so that was ok, it wasn't confusing. Now, nobody knows what's normal any more and it changes all the time. Maybe there will be a reaction in the next generation or maybe people will just start to walk naked like Germans, which wouldn't be attractive, but maybe a little bit healthier. It's a very funny area. If you think about it, on paper, then nudism is a good and healthy thing because our body is natural, why should we be ashamed? Everyone is equal when they're naked, etc, etc. The reality is that when you are among naked people it's not like that, and nudists are always a little bit creepy. But, maybe, that's because we come from a society which inherently regards the human body as shameful and, maybe, in two hundred years, societies will have evolved and we'll be over that. Who knows! But, still, in a movie, when you see a naked person you either say, "I want to see a little bit more" or "Oh, my God! Put it away". It's one or the other, it's never, "That's fine. That's natural". There's always a reaction that you have that you don't have to the clothed person. So, it's still open to question how that will ever be reconciled with the liberal society. People idealise the past and they talk about the Greeks having the Olympics in the nude and everyone believe that it would be wonderful if it could be like that. But people aren't thinking that, they're actually thinking, "Wouldn't it be great if the Olympics were in the nude and you could see them all day?”. At the time, you know there's a lot of letters about lechers and homosexuals rubbing their hands together at the thought of nineteen year old boys running around with their willies shaking all over the place. It's not easy and, again, it has got a lot of comic potential.

You don't like to be labelled as an 'Irish writer'. The Ireland of your novels never corresponds to the stereotype of the nice, green island, but it is more often a hard country to live in, even a sort of prison for many of the young protagonists. What is your attitude towards Ireland and 
Wexford? Why did you leave? Would you go back to live there?

Yes... I think so, especially now. It's so much nicer. Well, it's nicer in some ways, but, in other ways, people have more money now. It's nicer because people's attitudes are more easy, it's less nice because people have more money in the way that the eighties happened here in England and it's all a bit like a flash, new cars and new bungalows, it's quite distasteful. My attitude to Ireland is probably like that, but, possibly, I would feel like that about wherever I grew up. You know, if I had grown up in Italy, or India or even England, I would probably feel that it was pretty suffocating. The country of my childhood was particularly claustrophobic, but then so were a lot of places. I don't think that I've ever really objected to being labelled as an Irish writer. It's true that I object to labels in general. I object to the idea that my writing should be more Irish, because I am an Irish writer. So, people then say that I'm not very Irish, but I'm completely Irish. It's not me that has to change to fit the definition of what an Irish writer is, but, if I am an Irish writer, then the definition of Irish has to change to accommodate me. That's what I think. They can't make me "not Irish" and they can't make me behave more like an Irish person, so, therefore, they need to widen their definition and open their minds a bit and think, "Ok, you're Irish and you can be also like this". Maybe, twenty years ago it was more extraordinary, but now, when I meet writers who are younger than me, I don't seem so weird as I did, I think. I have huge objections to playing the Paddy just as I have objections to professional Englishmen or professional Italians or anyone who goes around making their personalities a clichéd form of their nationality. I find that repulsive in any nationality. I don't see anything wrong with being called an Irish writer, because that's what I am. At the same time, I don't see what's such a big thing about it. I don't see the way to restrict or define my writing. In much the same way it's the gay writing sticking in the gay shops. It's just stupid and pointless. It's always the people who don't read books who want to categorise them like that. Because if you can find the right category for the book, then you never have to read it.
In Evelyn Cotton, the narrator of the story is also a character directly involved in the events. But his constant dialogue with the reader, the numerous references to the misleading nature of his memory which makes him a completely unreliable narrator and the admission of the therapeutic role of his writing, seem to suggest a metanarrative consciousness that makes him closer to the position of an author inventing a story for a public than to that of the shy lover as he likes to present himself. Do you think this narrator has much in common with postmodernist theories of metafiction?

That's hard, I'm not sure what postmodernist theories of metafiction are. I can guess what they're meant to be...It's because the inherent beauty of fiction is that the word "fiction" means it is a lie, basically. If you are going to tell your story and say, "this is how it happened" and that there is only one way it could have happened, that's a very primitive idea. Anyone who thinks about it probably knows that it is not true, anyone who has ever been with their brother or sister discussing something that happened when they were three years old. They go, "No, no, no, that was another time, you're mixing up two stories". But you do mix up two stories because you're making a story. Even non-writers make stories, dreams are story-making and that's the only way of staying safe and making sense of your past and your present. So, for the narrator to admit his fallibility -even God has to admit his fallibility when he becomes a narrator- I think is essential because there is a level where only that can make the story emotionally true. Only when the story becomes unreliable, you believe that it's a real story coming from a person. The thing for me is to try to get away from the authorial voice -author is more than half of the word authority- one who makes the truth. It's not, it's fiction, you're giving a version of the events and it's only one of the many versions, it just gives you a little more understanding. When you write fiction it's not to say that is factually proved, it's to say, "I author, or narrator, or the characters within it, have a reason for perceiving it this way". I mean, when I have facts, I try to make sure that the facts are true. I think the attainable facts should be true, the dates, the places, the geography; 
and then the human facts must be human, must be fallible, because, otherwise, it's just not a human story, it's not a story the way a person perceives it. For instance, when you're gossiping with your neighbour, you know it's a prejudiced account and you know it's not quite true and you know it's a little bit invented and you know there are missing bits, but the more it's likely and the more fascinating it is. And the way that character changed the story is the greatest insight into that character.

The crisis of the family is another important topic of your writings. In your novels, parents seldom understand or love their children. Did your own experiences as a child and as a young boy influence the description of family traumas of your novels?

I really think that it's almost impossible for a parent to understand his own child. Here I am surrounded by people with young children and there is no question how much they love them, but I think they don't understand them. As a third, slightly disinterested party you can see what the child is thinking and what he's feeling more than the parent can, because the parent is mostly worried and that neurosis gets in the way to understand him. Then, from the child's perspective, loving and understanding are the same thing to a huge degree and, when you're a small child, when you feel unloved is always when you feel misunderstood. I think this is the human condition. Because I had an alcoholic father I had that in spades from his point of view, but then I had a very loving, understanding mother, although a Catholic one, who I could talk to and I felt understood me and I had a very good relationship with her. But, for some reason, I tend to avoid that in writing and I think that's because, maybe, I don't know how to control that yet. Even though it's now twenty-three years since she died, I still feel that if I wrote about that relationship I wouldn't write about it well, because it's too emotional, mawkish. And, you know, there's that kind of ghastly cliché about gay men and their mothers that I don't really want to go anywhere near. Family life is like hell while you're in it, but then, when you grow up and leave, you find that these brothers and sisters who you've fought with for twenty years suddenly become very good friends. They are people who understand you in a way that other people don't. Then, at the same time, if you spend more than two days with them, you want to kill them again. That's probably because they do or they think they understand you, or whatever. I don't see there is anything wrong with families, I just think the effects that families have on one's mind are interesting.

Your pessimistic representation of family ties seems to be extended even to the few children who are really loved and understood by their parents. It is the case of Rory Dixon, the hero of Dixie Chicken, who, despite his "childhood without prejudice or violence or hate" intended as a hippy experiment to "produce a well-balanced, fulfilled adult” (Ronan 1994: 77), becomes a sort of demon destroying the life of everyone close to him. What kind of childhood do you think can provide the basis not only for selfconfidence, as in the case of Rory, but also for a harmonic relationship with other people?

What I think now more and more is that the person is more important than the child ...I don't know, I feel terrible about it because the thing is, ideally, we're all supposed to believe in the natural argument that if you give a child the right environment, he'll grow up to be a good person. So, maybe, that was the question I was asking by making Rory Dixon. Rory wasn't a bad person, he was a sybarite and he was...well, he was hurting other people's feelings and that's probably what makes him a bad person [laughs]... but he never set out to do anyone harm, and never had evil intentions, but actually he does much harm. The novel was exactly about how much harm you can do to other people without intending them harm and, also, how that can happen without having a terrible childhood to blame it on. Since writing that novel I've had experiences which have led me to believe that there are people who are inherently evil and it doesn't matter what their upbringing is, they will be evil anyway. If they had a bad upbringing they'll blame it, but they're just bad. Sometimes animals are evil, too, so it's probably just the circumstances of nature. I don't like to say it, because it's a reactionary thing to say, it's Calvinistic predestination, it's anti all the nice, liberal ideas of the sixties and seventies. And there's also Rousseau, who was a bloody drip, too much of a self-apologist, I've always found him a dishonest writer. The truth lays somewhere in between, of course. Bad upbringings can make people worse and good 
better, so it's better when people have good upbringings, are educated and have their chances in life. It's a very difficult question, that's something I think about a lot and, maybe, you should come back in another forty years and ask me again and, maybe, still then, I wouldn't know. But it is one of the big questions of the culture and nature argument. I've not had nearly enough time and energy to spend asking myself.

Many of your novels explore love. Evelyn Cotton, A Picnic in Eden and Dixie Chicken seek to find a definition for this feeling, but rather end up defining what it is not. You seem to suggest that the brink of fulfilment could be better than what follows and that desire is probably what people like to call 'love'. Did you mean to say that love, as it is commonly thought about, is just an hypocritical idealisation of human relations?

No. I just haven't written that book yet. Again, it would be a very difficult book and the thing about love is not that you have this kind of ideal expectations and then it all goes horribly wrong and that's the end of it. I mean, what actually happens is that, eventually, after you've done that two or three times, you can get fed up going through the cycle and you think, "well, I don't care, I'm going to stick with it even if it really is awful". That's when it becomes really wonderful, it becomes better than all your airy fairy expectations in the beginning. Actually, you know, love is not a romantic thing. Love is a very down to earth thing, in the end. But I haven't written that book. I've just written the one which only gets two thirds of the way through the cycle. Sorry.

The story of Lovely examines love as a mean of self-destruction. In fact, Aaron is very tenacious in his ideal of love, despite Nick's brutality and selfishness. In this case, love is not an impulse beyond human control, but rather a rational decision on the part of Aaron. In my opinion, the novel strongly criticises the empty obsession for true love typical of our society. Why did you create two characters without possibility of redemption like Aaron and Nick?
The reason why I created Nick was the result of the experience that $\mathrm{I}$ had in which I discovered that there was such thing as an inherently evil person. Nick is an illustration of an inherently evil person. People like that manipulate people, and someone like Aaron, who is intelligent and worldly and sophisticated, doesn't realise that he can be manipulated. He was always going back to Nick because he was too arrogant to accept defeat. That is what the story was about.

\section{Which is the novel you feel more intimately bound to?}

I have a lot of affection for The Better Angel, which is my baby novel. Fair enough, it's the one that my friends always say that is my best. But that's maybe because it's the only one my friends have read. I don't know...I really couldn't say. The novels you wrote are behind you, you must leave them behind you. The one that you're obsessed with is the one you haven't finished and you can't wait for that to be behind you. So you don't have favourites in that way, but you just leave them behind you. Certainly, I can tell you that the one I am most glad to have left behind me, that I really don't like, is Lovely. But this doesn't mean that it is a bad novel, it was just a novel that was very traumatic for me to write.

\section{Works Cited}

Gardiner, Gerard.1989. "Frank Ronan: The Men Who Loved Evelyn Cotton". The Times Literary Supplement, $19^{\text {th }}$ May.

Boland, James.1996. “The Unimportance of Being Irish”. The Irish Times, $17^{\text {th }}$ February.

Ronan, Frank.1989. The Men Who Loved Evelyn Cotton, London: Bloomsbury.

1991. A Picnic in Eden, London: Bloomsbury.

.1992. The Better Angel, London: Bloomsbury.

1994. Dixie Chicken, London: Hodder \& Stoughton.

.1996. Lovely, London: Hodder \& Stoughton.

Stoughton.
2002. Home, London: Hodder \& 